\title{
Arbejdsmiljø og karriere \\ - to ph.d.-udfordringer
}

Trine Bovbjerg, HR-konsulent, Aalborg Universitet.

Monika Janfelt, fil.dr., karrierekonsulent, Kompetence- og organisationsudvikling, HR-Service Syddansk Universitet.

Hanne Dauer Keller, cand. psych., ph.d. og lektor, Institut for Læring og Filosofi, Aalborg Universitet.

\begin{abstract}
Artiklen afrapporterer de erkendelser omkring ph.d.-studerendes arbejdsmiljø og karriereudvikling, som vi har opnået i gennemførelsen af et udviklingsforløb for ph.d.-studerende på fire af landets universiteter $i$ 20122013. De ph.d.-studerendes arbejdsmiljø er ikke særligt velbelyst, og igennem en analyse af deltagernes udviklingsplaner og evalueringer af forløbet vil vi pege på 4 karakteristikker ved arbejdsmiljøet: Work-life-balance, dobbelt identiet som både studerende og medarbejder, forventninger og krydspres samt usikre karriereveje. De ph.d.-studerende trives pga. engagementet $i$ deres faglige forskningsprojekt, mens deres udfordringer med arbejdsmiljøet primært bunder $i$ kollegiale, ledelsesmæssige og organisatoriske forhold. For at fä inspiration til forbedringer af de ph.d.-studerendes arbejdsmiljø foreslås det at anlxgge et situeret laringsperspektiv på ph.d.uddannelsen. Et situeret perspektiv inddrager dele af arbejdsmiljøet som væsentlig faktor for faglig udvikling.
\end{abstract}

\section{Indledning}

Arbejdsmiljøforskningen har i de sidste 30 år været igennem en udvikling, hvor fokus i stigende grad er drejet hen på betydningen af det psykiske arbejdsmiljø. Det immaterielle arbejde er præget af udfordringer såsom fleksibilitet og store frihedsgrader, som ofte er et positivt gode for den enkelte, der gør, at man kan forfølge sine ambitioner i et interessant arbejde samtidigt med, at familie- og fritidslivet også kan passes. Der er også potentielle skyggesider: Det grænseløse arbejde, arbejdets mangetydighed og oplevelsen af for stort personligt ansvar - faktorer, der kan resultere i ubalancer og stressreaktioner. (Buch, Andersen \& Sørensen, 2009). 
Det psykiske arbejdsmiljø er naturligvis lige så vigtigt for de ph.d.-studerende som for alle andre, men der mangler i den grad fokus på arbejdsmiljøets ${ }^{1}$ betydning for de ph.d.-studerende. Der er få undersøgelser af deres arbejdsmiljø, og på arbejdspladserne synes der også at mangle fokus på betydningen af arbejdsmiljøet for denne gruppe. Der er meget få formelle tilbud til de ph.d-studerende om at tilegne sig kompetencer til at navigere i arbejdsmiljøet. Et tjek på kursusmulighederne (phdcourses.dk januar 2013) for ph.d.-studerende afslører 4 kurser (ud af 596), der adresserer arbejdsmiljøfaktorer i en eller anden grad, enten med fokus på at gennemføre ph.d.-studiet eller refleksion over og stillingtagen til fremtidigt karrierevalg. De ph.d.-studerende er heller ikke altid repræsenteret i universitetets samarbejdsudvalg. Da det er samarbejdsudvalgene, der arbejder med det psykiske arbejdsmiljø på universiteterne, kan dette medføre, at der mangler opmærksomhed på de ph.d.studerendes særlige vilkår, og dermed kan der tillige mangle evne og vilje til at forbedre deres forhold. ${ }^{2}$

Når der tales, skrives og forskes så lidt, som der gør, i arbejdsmiljøet på landet universiteter generelt og for de ph.d.-studerende i særdeleshed, kommer der til at mangle et sprog at føre dialogen i. Det er vanskeligt at tale om og diskutere, hvad der er positivt, og hvad der er problematisk ved arbejdsmiljøet, og hvordan det kan forbedres, når man ikke ved, hvilke faktorer der er væsentlige, og hvordan de påvirker arbejdsmiljøet. Det er derfor vigtigt at skabe større synlighed og sproglighed omkring de ph.d.-studerendes arbejdsmiljø og at overveje, hvordan de ph.d.-studerendes arbejdsmiljø kan forbedres.

I det følgende vil vi præsentere de væsentligste resultater og diskutere vores erfaringer fra et netop afsluttet karriereudviklingsforløb for ph.d.-studerende. Artiklen er baseret på data fra de deltagende ph.d.-studerendes personlige udviklingsplaner samt evalueringerne af forløbet. Materialet giver viden om de ph.d.-studerendes oplevelser af og erfaring med arbejdsmiljøet. Udviklingsplanerne har karakter af fænomenologiske data, der siger noget om, hvordan ph.d.-studiet opleves fra et subjektivt livsverdensperspektiv (Brinkmann og Tanggaard, 2010), og de kan derfor bidrage til vores forståelse af de ph.d.-studerendes arbejdsvilkår og hvilke områder, det er

\footnotetext{
${ }^{1}$ I denne artikel beskæftiger vi os med det psykiske arbejdsmiljø, der er en samlebetegnelse for de psykologiske, sociale og organisatoriske faktorer i arbejdsmiljøet, der påvirker medarbejderen. Arbejdsmiljøet inkluderer også fysiske, biologiske, kemiske og ergonomiske faktorer, men disse faktorer er ikke en del af artiklens fokus. Når vi bruger betegnelserne arbejdsmiljø og arbejdsmiljøfaktorer henvises kun til det psykiske arbejdsmiljø og faktorer af relevans for dette.

${ }^{2}$ Det har ikke været muligt at få tal på, hvor mange ph.d.-studerende der sidder i universiteternes samarbejdsudvalg, men fra vores egne erfaringer fra to af landets universiteter ved vi, at denne gruppe ofte ikke er repræsenteret direkte. I samarbejdsudvalgene sidder repræsentanter fra relevante fagforeninger, og da ph.d.-studerende ofte er nye på arbejdspladsen og har en tidsbegrænset ansættelse, er det sjældent dem, der vælges til dette tillidserhverv.
} 
vigtigt, at universiteterne giver større opmærksomhed. Karriereudviklingsforløbet i sig selv kan inspirere til afvikling af lignende forløb, der sætter fokus på arbejdsmiljøet og karriereudvikling, og giver de ph.d.-studerende redskaber til at reflektere, træffe gode valg og navigere i forhold til arbejdslivet. Vægten vil i denne artikel lægge på de arbejdsmiljømæssige aspekter af forløbet.

\section{De ph.d.-studerendes arbejdsmiljø}

Det er vanskeligt at finde forskning om arbejdsmiljøet for de ph.d.-studerende, men Dansk Magisterforening har lavet en rapport om de ph.d.-studerendes forhold, og Aarhus Universitet har offentliggjort en rapport om de ph.d.-studerendes arbejdspladsvurdering (APV) fra 2009. Samlet peger de to rapporter i retning af følgende væsentlige faktorer:

1. Ph.d. studiet er helt overvejende valgt pga. det faglige indhold og muligheden for at forske i et emne, som interesserer en. Muligheden for faglig fordybelse skaber stor trivsel, engagement og tilfredshed.

2. Der er størst tilfredshed med forskningsopgaver - mindre med undervisning og mindst med administrative opgaver.

3. Der er positiv vurdering af omfang og kvaliteten af vejledningen.

4. De faktorer, der opleves mindre positive, er: Uklare krav til afhandlingen, usikre forskerkarrieremuligheder, ensomhedsfølelse og manglende oplevelse af socialt fællesskab, stort arbejdspres, ujævn fordeling af arbejdsopgaver samt høje krav. Faktorer der gør, at man føler sig udkørt, og betyder, at arbejdet går ud over privatlivet.

Det er slående, at der er meget stærkt fokus på faglighed og forskning. Det er de positive og negative faktorer knyttet til mulighederne for forskning og faglig udvikling, der først og fremmest italesættes som væsentlige. Det er selvfølgelig ikke overraskende, men det er dog påfaldende, så lidt samarbejde med kolleger, godt lederskab og psykologiske trivselsfaktorer som anerkendelse umiddelbart betyder for de ph.d.studerendes trivsel.

Generelt minder de ph.d.-studerendes arbejdsmiljø meget om de karakteristika der fremhæves om vidensarbejde. Ifølge Buch og Andersen (2009) kendetegner følgende arbejdsmiljøfaktorer bl.a. vidensarbejde: Professionalisme, høj kvalitet i arbejdet og selvledelse. Disse fører dels til positive forhold såsom udøvelse af faglighed, mulighed for udvikling, autonomi og anerkendelse, men de fører også til belastende forhold i form af for meget arbejde, for forskellige arbejdsopgaver, uklare mål, uforudsigelighed og usikkerhed (ibid. s. 591). På nogle punkter adskiller ph.d.-arbejdet sig dog fra denne generelle karakteristik. Hvor vidensarbejderen typisk har mange samarbejdsrelationer, er organiseret i teams og oplever sin leder som støttende, arbejder den ph.d.-studerende meget alene og får primært en faglig ledelsesmæssig støtte gennem relationen til vejlederen. 
De ph.d.-studerende skal som alle andre vidensarbejdere lære at navigere i deres arbejdsmiljø og håndtere de belastninger, de oplever, på konstruktive måder, for at belastningerne ikke fører til reaktioner som stress eller udbrændthed. Da et ph.d.studie er tidsbegrænset, så er der i ansættelsen indlejret en usikkerhed omkring fremtidigt tilhørsforhold. Denne usikkerhed kan være mere eller mindre belastende, og aktiviteter, der kan dæmme op for de belastende aspekter, kan derfor anskues som positive for arbejdsmiljøet. Karrieremuligheder kan derfor anskues som en del af arbejdsmiljøet. For at understøtte de ph.d.-studerende valgte vi derfor at tilbyde et kursus med fokus på arbejdsmiljø og karriereudvikling.

\section{Beskrivelse af udviklingsforløbet}

Forløbet og den måde vi valgte at bygge det op på udsprang af ønsket om at give de ph.d.-studerende mulighed for at opøve deres evne til at mestre deres arbejdsmiljøudfordringer med særligt fokus på karriereudvikling. Formålet var at gøre de ph.d.studerende mere bevidste og inspirere dem til at træffe trivselsfremmende valg i deres arbejdsliv og give dem nogle praktiske værktøjer til stresshåndtering, prioriteringer og karriereplanlægning. Vores fokus lå på det subjektive, psykiske arbejdsmiljø (Agervold, 1998); dvs. trivsel og belastning som resultat af personlige bearbejdninger af ydre miljøfaktorer. Vi ville gerne hjælpe deltagerne til at få større klarhed over, hvad der var vigtigt for dem i deres arbejdsmiljø og deres arbejdsliv, samt hvordan de kunne håndtere de problematikker, der påvirkede dem. Da usikkerheden om fremtiden er stor og karrierevejene utydelige, uanset om man vil gå forskervejen eller en anden vej uden for universiteterne, bliver karrierespørgsmålet en væsentlig faktor i det psykiske arbejdsmiljø.

At vi havde fokus på det subjektive, psykiske arbejdsmiljø betød, at vi udformede workshopdagene, så de var så åbne i strukturen, at deltagernes egne erfaringer og erkendelser blev det bærende. Formmæssigt bød dagene på korte oplæg, øvelser, diskussioner og fremlæggelser, der gav plads til, at deltagerne kunne arbejde ud fra og med deres personlige udgangspunkt. Mellem workshopdagene var indlagt to præferencetests med efterfølgende individuel opfølgning med en konsulent. Her var fokus på betydningen af personlige præferencer for personens oplevelse af arbejdsmiljøet og hans/hendes karrierevalg.

Kurset blev tilrettelagt med følgende aktiviteter:

- Deltagelse i heldags-workshop omkring arbejdsmiljø.

- Gennemførelse af JTI-test (Jungs Type Indikator) samt $1 \frac{112}{2}$ times individuel tilbagemelding med konsulent.

- Deltagelse i workshop om karriereudvikling og kompetenceafklaring. 
- Gennemførelse af en karrieremodel-test (Decision Dynamics Career Model) samt $1 \frac{1}{2}$ times individuel tilbagemelding med konsulent.

- Individuel, skriftlig udformning af egen udviklingsplan.

- Deltagelse i afsluttende netværksmøde.

Forløbet blev afviklet i perioden fra februar 2012 til januar 2013 med ph.d. studerende fra København Universitet (KU), Syddansk Universitet (SDU), Aarhus Universitet (AU), Aalborg Universitet (AAU) og med artiklens forfattere som gennemgående undervisere. ${ }^{3}$ De ph.d.-studerende på KU, SDU og AU repræsenterede alle hovedområderne, mens der på AAU-holdet kun var ph.d.-studerende fra samfundsvidenskab og humaniora. Der var på alle universiteter en overvægt af kvinder, som havde tilmeldt sig udviklingsforløbet. I alt deltog 47 kvinder og 21 mænd.

\section{Analyse af deltagernes udviklingsplaner}

Deltagerne skrev som led i kurset en individuel udviklingsplan på 1-3 sider, bl.a. om, hvad de fik ud af kurset, og hvad de ville bruge erkendelserne til fremadrettet. Der var mange, som havde fokus på udbyttet af præferencetestene (JTI og karrieretesten) og på, hvordan personlige præferencer kunne spille ind på trivsel i deres nuværende og fremtidige arbejdsliv. I det følgende fremlægges vores analyse af de ph.d.-studerendes arbejdsmiljørelaterede udfordringer. Vi har gennemgået udviklingsplanerne (i alt 48 fra alle 4 forløb) og kategoriseret de udsagn, der relaterede sig til deres opfattelse af arbejdsmiljøet. Disse er udformede som frit formulerede narrativer, og de kan derfor ikke bruges til at dokumentere og udlede mere statistiske påstande om, hvor mange der mener noget om nogle bestemte parametre. Der skal også gøres opmærksom på, at de ph.d.-studerende kan opleve stor trivsel og tilfredshed i deres arbejdsliv uden, at det kommer til udtryk i deres udviklingsplaner. Analysen er derfor fokuseret på de problemområder, de ph.d.-studerende oplever, og giver ikke et komplet billede af de ph.d.-studerendes oplevelser af deres arbejdsmiljø.

Der er primært fire problematikker, vi vil fokusere på her: Det grænseløse arbejde, identitet som studerende eller medarbejder, forventninger til ph.d.-arbejdet og usikre karriereveje.

\section{Det grænseløse arbejde og problemer med work-life-balancen}

At gennemføre et ph.d.-projekt er en udfordrende arbejdsopgave. Vi ved bl.a. fra et udviklingsforløb med fokus på ph.d.-coaching, at der er belastninger forbundet med arbejdets forskningsfaglige indhold og organisering, og at en af de ph.d.-studerendes største udfordringer er "projektledelse og det at finde en god work/life balance" (Godskesen m.fl., 2013, s. 4). Citatet fanger problematikken i en nøddeskal: Det er

\footnotetext{
${ }^{3}$ Projektet var forankret på Syddansk Universitet med Monika Janfelt som projektleder og støttet af Statens Center for Kompetenceudvikling (SCK).
} 
vanskeligt at lære at drive et 3-årigt forskningsprojekt med alt, hvad det indebærer af faglige udfordringer, selvledelse og samarbejde med forskellige aktører. Samtidigt skal man have arbejdsindsatsen til at spille sammen med ens øvrige liv. Følelsesmæssigt slår udfordringerne igennem som usikkerhed i forhold til dagligdagens beslutninger og prioriteringer (Godskesen m.fl., 2013, s. 4).

Ønsket om at udvikle strategier til at forbedre work-life-balancen er et af de fokuspunkter, der ofte optræder i udviklingsplanerne. Der er ingen grænser for mulige arbejdsopgaver i et ph.d.-projekt. Dertil kommer den grænseløshed, der følger af ph.d.-arbejdets immaterielle natur og af, at udførelsen i vid udstrækning er uafhængig af tid og lokalitet. Man kan arbejde hele tiden og overalt, hvilket medfører, at man potentielt altid er på arbejde. Man skal tage et aktivt valg, hvis man i et tidsrum skal vælge arbejdet fra og familien eller fritiden til.

\section{Identitet som studerende eller medarbejder?}

De ph.d.-studerende er ansat som medarbejdere på institutterne med de rettigheder og pligter, der følger heraf, men de har samtidig titel af studerende og de tager en ph.d.uddannelse og ligner på den måde de øvrige studerende på universitetet mht. status. Det kan således være et åbent spørgsmål, hvordan de ph.d.-studerende selv og andre aktører på arbejdspladsen anskuer deres identitet. Indgår de i de konkrete arbejdsfællesskaber på lige fod med de øvrige kolleger, eller er de der midlertidigt med en form for særstatus som studerende? Disse tvetydigheder udtrykkes tydeligt i følgende citat:

"Jeg bemærkede, at kurset kunne give os ph.d.-studerende en identitet som faktiske medarbejdere med rettigheder og muligheder for at stille krav og sige til og fra. Det kunne flytte os vak fra at betragte os selv som nogen, der skal vxre taknemmelige for den position, vi besidder, og som skal gøre en ekstra indsats for at få lov at blive."

Den taknemmelige position synes at være normen, og det betyder, at de ph.d.studerende i vid udstrækning undlader at stille krav til deres vejleder, øvrige ledere og arbejdspladsen som sådan. Den taknemmelige position resulterer tillige $i$, at de ph.d.-studerende får for meget at lave, fordi de har vanskeligt ved at sige nej til opgaver, de bliver tilbudt. Selvom de tilbudte opgaver ikke altid er projektrelevante, kan det af karrierestrategiske årsager alligevel være vigtigt eller nødvendigt at sige ja til at udføre opgaverne. De ph.d.-studerende kan have svært ved at vurdere den karrieremæssige værdi og forudsige afkastet. Da konsekvenserne er usikre, vil de ph.d.studerende have tendens til at påtage sig opgaverne for en sikkerheds skyld. Flere af deltagerne i forløbet formulerer det som et udviklingsmål, at de skal "turde sige nej til undervisningsopgaver, der ikke er relevante for projektet." Ved at benytte ordet 'turde' understreges det, at det ikke er uvæsentligt, om man takker nej; der er tværtimod noget på spil, og man kan risikere noget ved at sige nej, såsom ikke læn- 
gere at blive tilbudt opgaver, og derved på sigt bliver mindre betydningsfuld for gruppen. Omvendt kan det at påtage sig opgaver være et skridt i retning af større integration i, opdyrkning af position og identitet som medarbejder og kollega i arbejdsfællesskabet. Opgaver, der ligger i periferien af projektet, kan også give erfaringer, der kan bidrage til afklaring i forhold til valg af karriereretning.

\section{Forventninger og krydspres i ph.d.-arbejdet}

Samtidigt med, at de ph.d.-studerende kan være usikre på, om de træffer de rette faglige valg, oplever de, at der er høje krav til deres indsats, og at der er hårde deadlines, der skal overholdes. Der er tale om en form for krydspres, hvor de forventes at levere i forhold til en projekteret 3-årig projektplan samtidig med, at planen baserer sig på en række faktorer uden for den ph.d.-studerendes kontrol. Meget kan ske på 3 år med de samarbejdspartnere, man er afhængig af. De ph.d.-studerende kan derfor opleve usikkerhed omkring hvordan, de træffer de rigtige faglige valg og hvordan, de mest hensigtsmæssigt organiserer deres tid, og derved føle usikkerhed over deres egen faglige formåen. På den måde er en væsentlig arbejdsmiljøfaktor i ph.d.-arbejdet usikkerheden omkring, hvad det er bedst at gøre (Beck, 1997).

Flere deltagere fremhæver, at en af de ting, de har fået ud af kurset, er en øget bevidsthed om nødvendigheden af, at de forholder sig aktivt til deres arbejdsliv og stiller krav eller siger til og fra i forhold til, hvad de selv trives med:

"Hvor jeg før kurset måske havde en tendens til at forholde mig mere eller mindre passivt til forhold som studerende, jeg ikke var tilfreds med, holder jeg nu i højere grad fokus på at identificere og reflektere over, hoad jeg gerne vil."

Svaret på ph.d.-arbejdets iboende kompleksitet og modsigelser er, at den ph.d.studerende arbejder aktivt med at udvikle sin egen retning i arbejdslivet og en professionel integritet.

\section{Usikre karriereveje}

En fjerde faktor i arbejdsmiljøet hænger sammen med muligheden for at se sit aktuelle arbejde i et længere karriereperspektiv, udvikling af en identitet som forsker og oplevelsen af at være engageret $\mathrm{i}$ et projekt med tydelige fremtidsperspektiver. Et gennemgående tema i udviklingsplanerne er derfor spørgsmålet om karrierevalg og behovet for at få større afklaring af, hvilke veje man vil og kan gå:

\footnotetext{
"Kurset har gjort mig opmærksom på, hvilke kvalifikationer og kompetencer vi som ph.d.ere har ..., og hvordan en forskeruddannelse ikke nødvendigvis behøver at betyde en forskerkarriere, men at der er adskillige jobs i grænsefladen mellem forskning og $f x$ forvaltning."
} 
Karriereplanlægning, som noget man skal tage alvorligt og arbejde med, både på kort og lang sigt, er en indsigt, som flere deltagere skriver om i deres udviklingsplaner. Ligeså skriver en del om ansvar for egen karriere og for at træffe de rigtige valg som en erkendelse, de tager med sig fra forløbet:

"Det er min fremtid det omhandler, og jeg må tage større styring. ... Jeg er ved den første store skillevej i mit karriereforløb, og kurset har i den grad hjulpet mig til at erkende, at jeg må vælge og tage stilling og ikke frygte, at jeg vælger noget fra."

Deltagerne får således gennem kurset øjnene op for, at de har flere karrieremuligheder, og at de bør overveje hvilken karriere, de sigter på, da det har betydning for de valg, de træffer under studiet. Den universitære karrierevej er dog i bund og grund usikker, da der uddannes langt flere ph.d.ere, end der efterfølgende opslås stillinger til.

Hvis de ph.d.-studerende derfor skal gøre sig håb om at få forskerstillinger, oplever de, at de under studiet skal fremvise en facade, der signalerer, at de er et kommende medlem af det universitære praksisfællesskab. Det gør man ved at fremstå vidende, kompetent og sikker overfor omverdenen. Flere ph.d.-studerende gav derfor på kurset udtryk for, at de ikke oplever, at de kan dele deres usikkerhed og bekymringer med hinanden eller med vejlederen eller med andre kolleger i miljøerne. De vurderer, at det kan have negative konsekvenser for en mulig universitetskarriere, hvis de allerede under ph.d.-uddannelsen viser, at der er arbejdsopgaver, de finder vanskelige. Dette kan også tolkes af, at flere i deres udviklingsplaner fremhæver, at det har været en befrielse at deltage i dette kursusforløb, hvor det var legitimt at fremkomme med sine spørgsmål og bekymringer. Det fremhæves tillige i evalueringerne som positivt, at holdene har været sammensat på tværs af faglige miljøer, da det har bidraget til en åben og ærlig stemning.

\section{Hvad har vi lært om ph.d.-studerendes arbejdsmiljø?}

Udviklingsforløbet har vist sig meget relevant for deltagerne, da det har adresseret faktorer i arbejdsmiljøet, som der ofte ikke fokuseres på i de faglige miljøer. Der er nødvendige udfordringer og belastninger knyttet til det at skulle gennemføre et flerårigt projekt og selv være primært ansvarlig for at træffe de dertil knyttede teoretiske og metodiske valg. Forløbet har dertil kastet lys på en række ekstra udfordringer og belastninger, der ikke knytter sig til arbejdets indhold, men primært knytter sig til sociale, ledelsesmæssige og organisatoriske forhold: Problemer med work-life-balancen, identitet mellem studerende og medarbejder, krydspres og usikre karriereveje. Analysen har bragt os et skridt ad vejen til at forstå væsentlige dynamikker i de ph.d.-studerendes arbejdsmiljø. 
Det skal påpeges, at ph.d.- studerende har mange forskellige oplevelser af det at være ph.d.-studerende, hvilket reflekterer universitetssektorens diversitet. Derfor er der også ph.d.- studerende, der ikke oplever de felter, vi peger på, som problematiske.

De områder, der primært bør udvikles, omhandler primært kollegiale, ledelsesmæssige og organisatoriske forhold. De ph.d.-studerende bliver ikke nødvendigvis medlemmer af det arbejdsfællesskab, som de skal være en del af. De bliver ikke nødvendigvis inddraget i undervisning, planlægning, udviklingsarbejde mm. i et forskningsmiljø. Derudover kan de ph.d.-studerende være usikre på, hvilken praksis de skal satse på at lære, da de ikke ved, hvorhen karrierepilen peger. Derfor kan den karrieremæssige usikkerhed, som mange ph.d.-studerende befinder sig i, påvirke de ph.d.-studerendes lærings- og socialiseringsprocesser negativt. På den ene side kan de selv være usikre på, om de skal bruge tid og ressourcer på at opdyrke kompetencer og relationer, der kan forbedre deres chancer for en universitetskarriere, og på den anden side kan de faglige miljøer være usikre på, om det er værd at investere tid og ressourcer i at inddrage og oplære de ph.d.-studerende i fællesskabets mere centrale opgaver. Disse usikkerheder er vigtige, hvis man anskuer læring ud fra et situeret perspektiv, hvor læring ikke kun handler om at udvikle teoretisk og metodisk viden men også om at udvikle fagets mere tavse elementer som fx dømmekraft eller fornemmelse for forskningsstandarder. For at udvikle kompetencer til at udøve et fag i et situeret perspektiv er det en nødvendighed at indgå i et praksisfællesskab med rollemodeller på forskellige niveauer af faglig udvikling og med adgang til de mere erfarnes viden (Lave og Wenger, 1991; Wenger, 1998).

I en analyse af forskeres læringsbaner peger Kvale (1999) på mesterlærens store betydning. Forskere lærer gennem deltagelse i praksisfællesskaber, hvor de til at starte med indtager en mere perifer rolle for langsomt at bevæge sig ind mod en fuldgyldig position i fællesskabet. I denne bevægelse tilegnes ikke blot viden og færdigheder men også normer og værdier, smag og dømmekraft. Processen fungerer identitetsskabende bl.a. ved, at de ph.d.-studerende identificerer sig med 'mestre' inden for feltet. 'Undervisningen' og evalueringen foregår ved, at 'mestrene' fungerer som rollemodeller, og på den måde indlæres både de mere eksplicitte sider af faget og de mere 'tavse', så som en holdning og en vision (ibid. s. 180ff). Et situeret perspektiv på de ph.d.-studerendes læring kunne give blik for vigtige sociale og identitetsmæssige dimensioner af læreprocessen og kunne være et redskab til at organisere nogle mere lærende miljøer. Pointen er, at der skal arbejdes aktivt med design af sociale læringsmiljøer for de ph.d.-studerende. Der er allerede nu gang i forskellige forsøg på at skabe mere støttende miljøer ved fx ph.d.-klubber og body- og mentorordninger og ph.d.-coaching. En anden pointe er, at man må forsøge at tilrettelægge ph.d.uddannelsen, så den studerende lærer den fulde universitetspraksis og ikke kun forskerpraksis. Ideelt set beriger forskning og undervisning hinanden, og et veltilrette- 
lagt ph.d.-læringsforløb bør formes, så der opstår synergi mellem forskningsinteresser, undervisningsopgaver og administrative opgaver. Hvis man skal tro vores erfaringer fra dette forløb, så er det en pædagogisk opgave, der ikke alle steder bliver løst i tilstrækkeligt omfang.

\section{Kan man lære at håndtere sit arbejdsmiljø og sin karriere ved at gå på kursus?}

De ph.d.-studerendes arbejdsmiljø byder på en række udfordringer og det synes oplagt, at problemerne skal løses gennem organisationsudvikling i miljøerne. Ved kun at tage problematikkerne op i kursusregi kan trivsel og godt psykisk arbejdsmiljø blive en individualiseret opgave, som følgende citat giver udtryk for:

"Jeg skal lære at sige nej, sådan stress ikke overtager min hverdag. Det betyder også, at jeg er blevet klar over, at jeg aktivt må gøre en indsats for trivsel."

På den anden side synes det relevant at styrke den enkelte ph.d.-studerendes refleksion over og stillingtagen til eget arbejdsmiljø og karriereudvikling. Udviklingsforløbet har hjulpet dem til at bearbejde mulige belastninger og til at stille krav til miljøet. Det har haft stor betydning, at de ph.d.-studerende har mødt andre i samme situation og oplevet, at kolleger tackler udfordringerne forskelligt. Det har også givet oplevelser af, at fx bekymringer og usikkerhed i forhold til egen karrieresituation var almene, og at det var legitimt at have sådanne følelser. Der var stor lettelse over at kunne tale åbent og ærligt omkring usikkerhederne i arbejdet som ph.d.-studerende.

\section{Afrunding}

Vi kan konkludere, at kursusforløbet har sat fokus på relevante tematikker, som der p.t. ikke er meget opmærksomhed på. Det drejer sig om betydningen af arbejdsmiljøet, karrierevejsvalg og personlige præferencer for ph.d.-forløbet. Bevidstheden om og sprogliggørelsen af disse temaer har givet deltagerne mulighed for at reflektere over og i fællesskab at diskutere emnerne og dermed blive klogere på betydningen af arbejdsmiljø og karriereudvikling.

Deltagernes udviklingsplaner har givet stof til, at vi i denne artikel har kunnet pege på fire karakteristika ved ph.d.-arbejdet: Det grænseløse arbejde, identitet mellem kollega og studerende, forventninger og krydspres i ph.d.-arbejdet og usikre karriereveje. De forbundne dynamikker har sociale, organisatoriske og identitetsmæssige dimensioner, og helt overordnet peger de mod, at ph.d.-uddannelsen i dag skaber læringsforløb, hvor der mangler mulighed for at deltage i bredere praksisfællesskaber og sigte målrettet mod at udvikle sig hen mod en bestemt arbejdsidentitet. 
Trine Bovbjerg arbejder som HR-konsulent ved Aalborg Universitet. Hendes faglige fokus er rekruttering, medarbejderudvikling og arbejdsmiljø. Hun har mange års erfaring med kompetenceafklaring, karriereudvikling, undervisning samt hele rekrutteringsprocessen for hhv. administrative og videnskabelige stillinger $i$ universitetssektoren. Hun har en baggrund som cand.mag. i Musikvidenskab og Historie - læs evt. mere på http://personprofil.aau.dk/119965\#/minside

Monika Janfelt arbejder som karrierekonsulent, projektleder og coach ved HR-Service ved Syddansk Universitet. Hendes faglige fokus er talentudvikling, rekruttering og karrierecoaching. Hun har mange års erfaring med at undervise, holde workshops, foredrag og seminarier samt med at afholde lederaspirant- og karriereudviklingsprogrammer. Hun har en baggrund som historiker og lektor ved Syddansk Universitet.

Hanne Dauer Keller arbejder som lektor indenfor feltet Organisatorisk Laring. Hun har i et 2-årigt pilotprojekt wæret tilknyttet HR-afdelingen på Aalborg Universitet og har virket som konsulent og arbejdet med psykiske arbejdsmiljø på universitetet på individ-, gruppe- og organisations-niveau.

\section{Litteratur}

Agervold, M. (1998). Det psykosociale arbejdsmiljø. Aarhus: Aarhus Universitetsforlag Beck, U. (1997). Risikosamfundet: På vej mod en ny modernitet. København: Hans Reitzels Forlag.

Buch, A. \& Andersen, V. (2009). Begejstring og belastning i vidensarbejdet. Psyke $\mathcal{E}$ Logos, 30(2). København: Dansk Psykologisk Forlag.

Buch A., Andersen, V. \& Sørensen, O. H. (2009). Videnarbejde og stress - mellem begejstring og belastning. København: Jurist- og Økonomforbundets Forlag.

Brinkmann, S. \& Tanggaard, L. (red.) (2010). Kvalitative metoder. En grundbog. København: Hans Reitzels Forlag.

Godskesen, M. m.fl. (2013). Coaching, netværk og udvikling af forskningsmiljøer med fokus på ph.d.-studerende. Aalborg Universitet.

Kvale, S. (1999). Forskere i lære. I: Nielsen og Kvale (red.): Mesterlære. Læring som social praksis. København: Hans Reitzels Forlag.

Lave, J. \& Wenger, E. (1991). Situated Learning - legitimate peripheral participation. Cambridge: Cambridge University Press.

Wenger, E. (1998). Communities of practice. Cambridge: Cambridge University Press.

\section{Internetsider}

Danmarks Magisterforenings ph.d.-undersøgelse kan downloades på http://www.dm.dk// /media/Nyheder/Phdundersoegelse.ashx?tttt=2 (tilgået 26.08.13).

Arbejdspladsvurdering for ph.d.-studerende på Aarhus Universitet 2009 kan downloades på: http://medarbejdere.au.dk/fileadmin/www.arbejdsmiljo.au.dk/apvportalen/publikationer/phd.pdf (tilgået 26.08.13) 